\title{
Access to opioid analgesics for palliative care patients in Ukraine: problems of past and present
}

\section{Abstract}

The results of research of the Ukrainian Palliative and Hospice Care League show that every year at least 600 thousand people with incurable illnesses (cancer, HIV/AIDS, diabetes, tuberculosis, and others) need palliative care. However, nowadays the realisation of the right to a dignified death for incurable patients is difficult because of numerous problems of legislative, organisational, technical, personnel, and moral-ethical nature. Therapy of chronic pain syndrome is a significant problem for palliative patients in Ukraine, who do not receive adequate analgesia. There is non-compliance with the World Health Organisation recommendations for pain relief, a strict and complicated legal framework for narcotic medicines and licensing of health care facilities (and the reluctance of such establishments to obtain a license), collisions with prescribing of opioids, fear of doctors to prescribe high doses of analgesics for patients, and the lack of appropriate skills and experience in the treatment of chronic pain in medical specialists. That is why the access of patients to analgesic drugs is limited.

However, despite the numerous problems, since 2013 there have been positive changes, in particular, on the writing of prescriptions for opioids for palliative care patients.

Palliat Med Pract 2019; 13, 4: 187-196

Key words: palliative care, opioids, availability, pain relief, legislation

\section{Abbreviations}

WHO - World Health Organisation

$\mathrm{PC}$ - palliative care

CPS - chronic pain syndrome

$\mathrm{OA}$ - opioid analgesics

MHU - Ministry of Health of Ukraine

HCF - Health care facility

$\mathrm{CMU}$ - Cabinet of Ministers of Ukraine

\section{Introduction}

Ukraine is a state located in Eastern Europe, which ranks second in the area among other European countries. According to the State Statistics Service, as of January 1, 2019, the population of Ukraine is about 42 million people with a mortality rate of more than 600 thousand people each year [1].

Address for correspondence:

Sofiya Shunkina

Danylo Halytsky Lviv National Medical University

e-mail: sofiyaprokip@gmail.com

Palliative Medicine in Practice 2019; 13, 4, 187-196

Copyright (C) Via Medica, ISSN 2545-0425

DOI: 10.5603/PMPI.2019.0022 
Table 1. Levels of consumption of narcotic drugs in defined daily doses (DDD) per million inhabitants per day in Europe, 2015-2017

\begin{tabular}{|c|c|c|c|c|c|c|c|}
\hline \multicolumn{2}{|c|}{ Ranking } & \multirow{2}{*}{$\begin{array}{l}\text { Country } \\
\text { (top 10) }\end{array}$} & \multirow{2}{*}{$\begin{array}{l}\text { Total } \\
\text { DDD }\end{array}$} & \multicolumn{2}{|c|}{ Ranking } & \multirow{2}{*}{$\begin{array}{c}\text { Country } \\
\text { (down 10) }\end{array}$} & \multirow{2}{*}{$\begin{array}{l}\text { Total } \\
\text { DDD }\end{array}$} \\
\hline Europa & Global & & & Europa & Global & & \\
\hline 1 & 2 & Germany & 28,862 & 33 & 47 & Poland & 2072 \\
\hline 2 & 4 & Austria & 21,109 & 34 & 48 & Cyprus & 1944 \\
\hline 3 & 5 & Belgium & 19,960 & 35 & 57 & Bosnia and Herzegovina & 1123 \\
\hline 4 & 6 & Switzerland & 19,204 & 36 & 58 & Romania & 1101 \\
\hline 5 & 7 & Denmark & 17,270 & 37 & 59 & Ukraine & 1067 \\
\hline 6 & 9 & Netherlands & 16,114 & 38 & 67 & Belarus & 628 \\
\hline 7 & 10 & Gibraltar & 15,988 & 39 & 70 & Albania & 601 \\
\hline 8 & 13 & Spain & 13,385 & 40 & 71 & Republic of Moldova & 596 \\
\hline 9 & 14 & Iceland & 12,955 & 41 & 79 & Lithuania & 410 \\
\hline 10 & 15 & United Kingdom & 12,575 & 42 & 98 & Russian Federation & 198 \\
\hline
\end{tabular}

Source: Authors' own development based on [14, 15]

The Ukrainian Palliative and Hospice Care League in its reports notes that each year more than 600 thousand people in Ukraine need palliative care (PC) services. These are patients with circulatory system diseases, including chronic heart diseases (almost 489,000 deaths per year), cancer $(100,000)$, respiratory diseases $(28,000)$, tuberculosis $(10,000)$, neurological disorders, including Alzheimer's disease (6500), and HIV/AIDS (about 2500) [2].

Patients with incurable diseases, in addition to treatment aimed at improving their physical condition, also need PC assistance for adequate pain relief and improved quality of life that is worsening because of symptoms such as dyspnoea, anxiety, and depression. However, according to the classification of the Worldwide Hospice Palliative Care Alliance, Ukraine belongs to the group of countries "with unsystematic provision of PC". The same status is also attributed to Armenia, Cuba, Egypt, Pakistan, Russia, and several other countries, which are similar in their lack of support for the palliative movement, the shortage of analgesics (in particular morphine), and small number of hospice and palliative units [3].

Pain management is an important part of PC. Thus, according to World Health Organisation (WHO) data, cancer patients need pain relief at all stages of the disease. About $80 \%$ of patients in the last stage of cancer, $50-80 \%$ of patients with HIV/AIDS, and $40-70 \%$ of patients with cardiovascular diseases suffer from pain, the intensity of which increases from moderate to severe in the later stages of the disease [4-7].

There is a generally accepted (by the world medical community) methodological approach to the development of the best clinical practice for the control and management of chronic pain syndro- me (CPS): the WHO three-step "ladder" for cancer pain relief. It was developed by a group of experts in 1982-1985 and published in 1986 as an official document. This "step-by-step" scheme of treatment includes analgesic drugs of certain classes (from weak to strong) with a gradual dosage increase (titration of dose) $[8,9]$.

The necessity of using opioid analgesics (OA) for the treatment of severe pain is shown by international clinical recommendations, such as WHO recommendations for cancer pain management $[9,10]$, clinical recommendations of the European Palliative Care Association on the use of opioids [11, 12], and guidelines of National Institute for Health and Care Excellence "Palliative care for adults: the use of strong opioids for pain relief" [13], and the "Unified clinical protocol for palliative care of chronic pain syndrome" of the Ministry of Health of Ukraine (MHU) [14]. Nevertheless, the availability of opioids for medical purposes remains a widespread problem for healthcare systems, especially in developing countries, including Ukraine, where the level of medical consumption of OA, according to the analysis of the International Narcotics Control Board, is more than 27 times lower than the same one in Germany, and almost twice as in Poland (Table 1). However, in comparison with the Russian Federation and the Republic of Belarus, consumption of OA in Ukraine is 5.4 and 1.7 times higher, respectively [14]. At the same time, according to the indicator of medical consumption of opioids, Ukraine takes $37^{\text {th }}$ place in Europe and $59^{\text {th }}$ in the world.

According to the content analysis of literature sources $[2,15-20]$, the main factors that may affect the availability of OA for patients and, as a consequence, adequate pain relief in Ukraine can be grouped into 


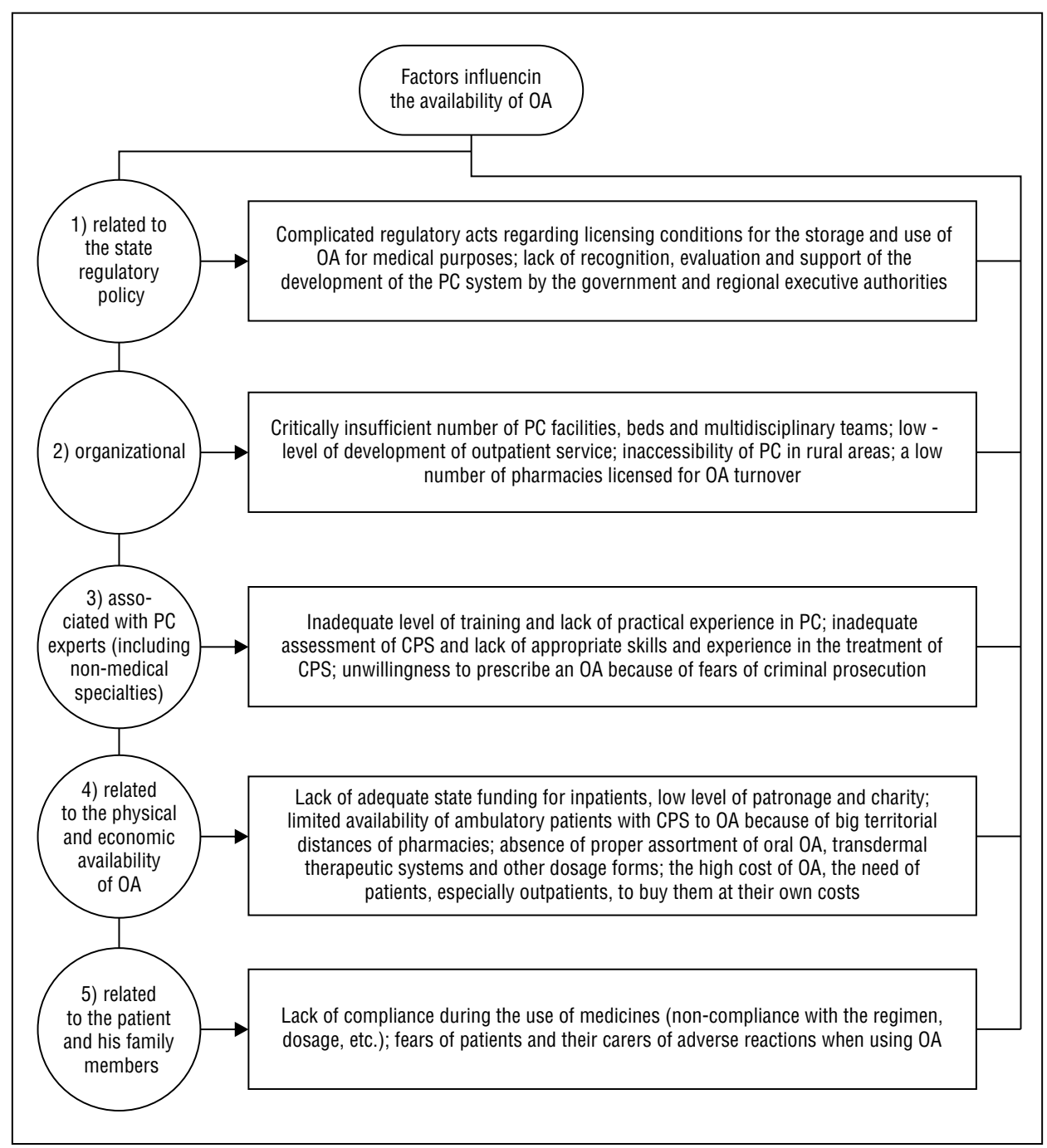

Figure 1. Groups of factors that may affect patients' access to opioid analgesics. Source: Authors own development based on $[2,15-20]$

five main groups: organisational, otherfactors linked to the state regulatory policy, PC specialists, the physical and economic availability of $\mathrm{OA}$, and the patient and his/her family members (Fig. 1).

Therefore, patients in a hospital, a hospice, a PC unit, or a general health care facility (HCF) can obtain analgesics from public money (of course, if they are available in this facility); morphine, hydromorphone/hydromorphine, and oxycodone are included in the National List of Essential Medicines as OAs for the treatment of pain in palliative patients, and they may be purchased from budget funds [21]. However, according to statistics, the amount of such patients is only $10-15 \%$. Most palliative patients in Ukraine stay at home, so if they do not receive morphine (or other medicines) from HCF or multidisciplinary team, then they must buy it in the pharmacy. And here the situation looks different. According to the
Resolution of the Cabinet of Ministers of Ukraine (CMU) No. 1303 dated August 17, 1998, patients with certain diseases have the right to get medicines from a pharmacy free of charge exclusively in the case of outpatient treatment of major disease (for example, cancer, tuberculosis, HIV/AIDS, diabetes, haematological diseases, etc.), for which the patients were provided by privileges. Therefore, cancer patients can get medicines only for the treatment of cancer, but not pain, because pain is just a symptom, not a main disease. Only patients with HIV/AIDS have the right to receive all medicines free of charge, and so they can get painkillers for free.

\section{Access to opioid analgesics: how was it?}

The problems of incurable patients, in particular qualified inpatient care and the proper provision 
of OA and care products, have not been considered and resolved in Ukraine on national or regional levels for a long time. There has been intensive creation of a network of palliative medicine units (hospices and PC departments in HCF) during the last 15 years. This was done mainly because of the initiative of various charitable foundations, and public and religious organisations. Several multidisciplinary teams for provision of help to patients at home have been created in the last five years. Inpatient PC is provided totally on 1500 beds, which is just over one third of the needs recommended by the WHO. There is no proper care system for incurably ill patients at home, although, according to the MHU statistics, most of the palliative patients (over $80 \%$ ) die at home without adequate pain relief, or social and psychological support [18-20].

In 2010, the Human Rights Watch, together with the Institute of Legal Research and Strategies (Kharkiv) and the All-Ukrainian Network of People Living with HIV/AIDS (regional offices in Rivne and Kyiv) conducted a study on the presence of pain relief and PC in Ukraine. The results were shocking because the main practices of PC were largely ignored, and providing patients with treatment in accordance with the principles of evidence-based medicine was impossible due to procedures of fighting with drug addiction. That is why analgesics for most patients were practically inaccessible.

The results of another survey conducted by human rights organisations show that the expected rates of successful pain relief in patients at the level of $80-90 \%$ of those in need have not yet been achieved. Conditionally successful analgesia is received by $5-14 \%$ of patients only [22]. The main and most significant problems with the availability of adequate pain control for the patients are listed in the Human Rights Watch report [2].

\section{Non-compliance with WHO} recommendations for pain relief, absence of oral morphine, and problems with the use of opioid analgesics injections.

Despite the WHO recommendations for oral morphine as a gold standard of cancer pain treatment, morphine in tablets was not registered in Ukraine until 2013, and in oral syrup - until 2016. Doctors prescribed injections of strong OA for pain relief. It significantly influenced the quality of patients' lives. In addition, due to the legal requirement of administration of OA injections to patients only by medical staff (doctor or nurse), patients did not receive the proper amount of the medicines because medical personnel were physically unable to visit patients at home six times a day (the WHO recommends usage of OA every four hours). Patients also suffered from an unreasonable limitation of the maximum daily dose of injectable morphine ( $50 \mathrm{mg}$, equivalent to $150 \mathrm{mg}$ of oral morphine), which is noted in the manufacturer's instructions, and it is much lower than the dose of morphine recommended by the WHO for the effective treatment of severe pain. Because most patients need 10-30 mg of oral morphine every four hours (60-180 mg per day), even those who are at the lowest levels of this typical range need more than the maximum recommended daily dose every four hours.

\section{The legal framework for narcotic medicines and licensing of HCF.}

The procedures for medicine turnover in Ukraine are stricter than required by United Nations drug conventions, and they contain numerous positions that directly inhibit the provision of palliative care. In particular, overly onerous bureaucratic requirements and fears of negative legal consequences discourage doctors from prescribing OA. In accordance with the legislation [23], HCF should obtain a license for storage, prescription, or dispensation of $O A$.

However, there are many criteria on the premises that must meet requirements before a license can be issued. They include a separate storage room for narcotic medicines, with certain thickness of walls and doors; a fireproof safe attached to the floor; the need for a special metal lattice; and for an alarm system. The abovementioned requirements are the main reason for the limited availability of OA in most establishments (both hospitals and pharmacies). The situation in rural areas, because often rural health posts and small pharmacies do not have separate premises for storing $O A$, is especially critical.

\section{Collisions with prescribing opioid analgesics for patients.}

Until recently, in order to obtain, for example, morphine in ampoules, the patient had to undergo a series of bureaucratic stages that delayed the process of pain relief. These are, in particular: an examination by the oncologist and his/her conclusion about the prescribing of $\mathrm{OA}$; a session of a medical commission (at least three doctors) and approval of its conclusion; approval of the conclusion by the chief doctor of the HCF; a record in the form of a medication administration card about the new patient's medicines (or a special prescription written by the doctor if the patient will purchase medicines at the pharmacy at his/her own expense); receiving $O A$ from a nurse in a hospital and visiting a patient at home for drug administration (or purchase of a medicine by the patient or his/her carer at the pharmacy according to special prescription and 
usage of it without a medical worker's assistance) (requirements according to the Order of the MHU No. 11 dated January 21, 2010, cancelled for today). It should also be noted that very often doctors refused to prescribe $O A$, explaining this either by the absence of prescription forms or strict prescription requirements, or the fear of potential drug addiction. Another barrier that significantly complicated receiving $O A$ by patients was the strict accounting of unused or empty ampoules in the case when the patient did not purchase the medicine at his/her own expense (and this is the majority of patients). Thus, in accordance with the requirements of the legislation (no longer valid Order of the MHU No. 11 dated January 21, 2010), the medical staff who directly visits the patient should record each operation in separate journals (during receipt of the medicine, when the drug is administered, when the ampoules are returned, etc.), as well as to collect empty and unused ampoules, which are then the subject to disposal procedures. All these factors together have led to unjustified inhuman suffering of patients.

\section{Education and knowledge of medical specialists in the principles of providing PC; in particular, pain treatment.}

Pharmacotherapy of pain in terminal patients is studied by students of higher medical institutions in Ukraine very fragmentarily when studying different disciplines, and doctors and medical staff need theoretical knowledge and practical skills from different aspects of the PC [15]. Some issues of PC are studied in the process of training nurses at the Andriy Krupynsky Lviv State Medical College, I.V. Radziyevska Cherkassy Basic Medical College, and Nursing School of I. Gorbachevsky Ternopil National Medical University [24]. Also, in Ukraine there is no proper postgraduate education system for doctors and nurses - only two medical universities in Kyiv and Ivano-Frankivsk, as well as Cherkassy Basic Medical College, have PC topics included in the study cycles of doctors and nurses. In fact, doctors and nurses who work in the PC study by themselves by visiting different conferences, seminars, and other information events, mostly organised by nongovernmental organisations supported by the MHU.

\section{Accessibility of opioid analgesics: what has changed in the legislation?}

During the second half of the $20^{\text {th }}$ century in Ukraine, because of fears about the spread of drug addiction, the regulatory requirements for the control of narcotic substances were intensified. Also, there were contradictory positions in these documents for a long time. Thus, domestic experts found a sharp decrease in the use of morphine hydrochloride for medical purposes following the entry into force of the Order of the MHU No. 356 dated December 18, 1997 [15].

The turning point for national legislation was 2013, when, thanks to the active cooperation of public organisations and the MHU, the Ministry of Internal Affairs of Ukraine, and the State Service of Ukraine on Medicines and Drugs Control, CMU Decree No. 333 dated May 13, 2013 was adopted. In the same year, oral morphine (immediate-release tablets of 5 and $10 \mathrm{mg}$ ) was first registered in Ukraine [25]. That was a significant breakthrough in domestic pain therapy, and it became another reason for the revision and adjustment of domestic legislation. The appearance of oral forms of OA in Ukraine and CMU Decree No. 333 greatly expanded the possibility of conducting adequate analgesic therapy for patients with CPS. The procedure of turnover of OA used for the treatment of CPS in Ukraine is regulated by the following normative and legal acts:

1. Law of Ukraine "About narcotic drugs, psychotropic substances, and precursors" No. 61/95-VR dated February 15, 1995 [26].

2. Resolution of CMU No. 770 dated May 6, 2000 "About approval of the list of narcotic drugs, psychotropic substances, and precursors" [27].

3. Order of MHU No. 360 dated July 19, 2005 "About approval of the rules for writing of prescriptions and requirements-orders for medicines and medical products, the procedure for the dispensing of medicines and medical products from pharmacies and their structural subdivisions, instructions on the procedure for storage, accounting, and destruction of prescriptions and requirements-orders" [28].

4. Resolution of CMU No. 589 dated June 3, 2009 "About approval of the procedure for the activities of the circulation of narcotic drugs, psychotropic substances and precursors, and the control over their turnover" [29].

5. Resolution of CMU No. 333 dated May 13, 2013 "About approval of the procedure for the purchase, transportation, storage, dispensing, usage, and destruction of narcotic drugs, psychotropic substances, and precursors in health care institutions" [30].

6. Order of MHU No. 494 dated August 7, 2015 "About some issues of purchase, transportation, storage, dispensing, usage, and destruction of narcotic drugs, psychotropic substances, and precursors in health care facilities" [31], instead of order of MHU No. 11 dated January 21, 2010 "About approval of the procedure for the turnover of narcotic drugs, 
psychotropic substances and precursors in health care facilities of Ukraine" [32].

Until 2015, the Order of MHU No. 11 was in force in Ukraine, which significantly restricted the prescribing of OA to patients. The main differences between Order No. 11 and the new valid normative documents (Resolution of CMU No. 333 and Order of MHU No. 494) are given in Table 2.

As can be seen from the data in Table 2, on some issues the Resolution of CMU No. 333 and the Order of MHU No. 11, which were in force during the same period of 2013-2015, contradicted each other, for example, in the storage volumes of OA in HCF, and also in the order of prescribing of OA to patients. With the cancellation of the Order of the MHU No. 11 the procedure for prescribing $\mathrm{OA}$ to patients was substantially facilitated: if previously the decision on the prescribing of an $\mathrm{OA}$ to patient for more than three days had to be taken by the commission of the HCF, now, regardless of the term of appointment, this is done only by the patient's doctor. It is also substantially facilitated that the administration of parenteral forms of OA may be carried out by a carer or family member of the patient, and not necessarily only by the medical staff of the health care institution where the OA has been prescribed. Significant progress is seen in the cancellation of the disposal of empty ampoules and blisters after using OA. Now only unused OA that have been received by the patient or his/her carer at a health care facility are disposed of. Doctors have the right to prescribe opioids for a 15-day course of treatment, indicating this on the prescription form, for PC patients at home.

In recent years, in particular since 2013, the rules for prescribing OA have changed significantly. A comparison of changes in prescribing OA for palliative patients is presented in Table 3. Thus, a significant simplification for patients was the cancellation of the maximum dose of dispensing $\mathrm{OA}$ on one prescription, as well as the cancellation of pharmacy attachment to a health care institution in one administrative unit (region, city, village, etc.). This means the possibility of purchasing drugs for a 15-day course of treatment in any pharmacy in Ukraine (which has an appropriate license) regardless of the institution where the prescription was written.

Table 2. The main common and distinct aspects in the issues of opioid analgesics turnover in normative documents

\begin{tabular}{|c|c|c|c|}
\hline No. & $\begin{array}{l}\text { Issues of OA } \\
\text { turnover }\end{array}$ & $\begin{array}{l}\text { Resolution of CMU } \\
\text { No. } 333 \text { dated May 13, } 2013 \\
\text { (currently valid) }\end{array}$ & $\begin{array}{l}\text { Order of MHU } \\
\text { No. } 11 \text { dated January 21, } 2010 \\
\text { (invalid from September 22, 2015) }\end{array}$ \\
\hline & & & $\begin{array}{l}\text { Order of MHU } \\
\text { No. } 494 \text { dated August 7, } 2015 \\
\text { (currently valid) }\end{array}$ \\
\hline 1 & $\begin{array}{l}\text { Activity on } \\
\text { turnover }\end{array}$ & \multicolumn{2}{|l|}{ It is carried out by HCF of all forms of ownership } \\
\hline 2 & Storage of OA & \multicolumn{2}{|c|}{$\begin{array}{l}\text { They are stored in premises that are in compliance with the requirements of the Ministry of } \\
\text { Internal Affairs for the objects and premises intended for carrying out activity related to OA } \\
\text { turnover; keys from safes, metal cabinets and premises in which OA are stored, and sealing } \\
\text { devices (if any) are kept by the responsible persons }\end{array}$} \\
\hline 3 & $\begin{array}{l}\text { Storage volu- } \\
\text { me of OA in } \\
\text { the pharmacy }\end{array}$ & $\begin{array}{l}\text { OA are stored in a storage room in volumes } \\
\text { not exceeding the pharmacy's 3-month } \\
\text { needs; in the manufacturing (pharmacist } \\
\text { technician) room OA are stored in an amo- } \\
\text { unt that does not exceed their daily need, } \\
\text { necessary for the production of medicines }\end{array}$ & This is not indicated \\
\hline \multirow[t]{2}{*}{4} & \multirow[t]{2}{*}{$\begin{array}{l}\text { Storage volu- } \\
\text { me of OA in } \\
\text { the HCF }\end{array}$} & \multirow[t]{2}{*}{$\begin{array}{l}\text { Storage volume of OA in the HCF should } \\
\text { be no more than a } 1 \text {-month need, and in } \\
\text { the office (post) - no more than } 7 \text {-day } \\
\text { requirements }\end{array}$} & $\begin{array}{l}\text { Storage volume of OA in the HCF should be } \\
\text { no more than a } 2 \text {-week need, and in the office } \\
\text { (post) - no more than 1-day need, and on } \\
\text { weekend (festive) days - 3-day need }\end{array}$ \\
\hline & & & $\begin{array}{l}\text { The volume of storage of OA for the following } \\
\text { month }(\mathrm{Km}) \text { in hospices, PC departments, } \\
\text { and health care institutions that provide } \mathrm{PC} \text { is } \\
\text { calculated by the formula: Km }=(\mathrm{K} 1+\mathrm{K} 2+ \\
\mathrm{K} 3 \ldots+\mathrm{Kn}) \times \mathrm{D} \times 1.25, \text { where } \mathrm{K} 1, \mathrm{~K} 2, \mathrm{~K} 3 \ldots \\
\mathrm{Kn}-\text { quantity of } \mathrm{OA} \text { per day, intended for } 1 \text {, } \\
2,3 \text {, and } \mathrm{n} \text { patients at the time of calculation } \\
\text { of storage volumes; } \mathrm{D}-\text { number of days in a } \\
\text { month }\end{array}$ \\
\hline
\end{tabular}


Table 2 cont. The main common and distinct aspects in the issues of opioid analgesics turnover in normative documents

\begin{tabular}{|c|c|c|c|}
\hline No. & $\begin{array}{l}\text { Issues of OA } \\
\text { turnover }\end{array}$ & $\begin{array}{l}\text { Resolution of CMU } \\
\text { No. } 333 \text { dated May 13, } 2013 \\
\text { (currently valid) }\end{array}$ & $\begin{array}{l}\text { Order of MHU } \\
\text { No. } 11 \text { dated January 21, } 2010 \\
\text { (invalid from September 22, 2015) }\end{array}$ \\
\hline & & & $\begin{array}{l}\text { Order of MHU } \\
\text { No. } 494 \text { dated August 7, } 2015 \\
\text { (currently valid) }\end{array}$ \\
\hline \multirow[t]{2}{*}{5} & \multirow{2}{*}{$\begin{array}{l}\text { A document } \\
\text { for accounting } \\
\text { of OA }\end{array}$} & $\begin{array}{l}\text { Special form of Journal defined by the } \\
\text { MHU }\end{array}$ & Special form of Journal 129-8/o \\
\hline & & \multicolumn{2}{|c|}{$\begin{array}{l}\text { The pages of the journal are numbered, bound, and sealed by stamp of the health care } \\
\text { institution and the signature of the chief doctor }\end{array}$} \\
\hline 6 & $\begin{array}{l}\text { The procedure } \\
\text { for the appo- } \\
\text { intment of OA } \\
\text { to palliative } \\
\text { inpatients }\end{array}$ & $\begin{array}{l}\text { OA are prescribed by doctors or medical } \\
\text { assistants (paramedics) in accordance } \\
\text { with the medical indications defined by } \\
\text { the MHU; the appointment of OA to the } \\
\text { patient for a period of more than } 10 \text { days } \\
\text { is carried out by a doctor with a compul- } \\
\text { sory justification for the need for further } \\
\text { use of OA, which is noted in the patient's } \\
\text { medical card }\end{array}$ & $\begin{array}{l}\text { OA are appointed by doctors of HCF in accor- } \\
\text { dance with medical indications; the decision } \\
\text { to appoint OA to patient for a period of more } \\
\text { than } 3 \text { days is made by the special medical } \\
\text { commission with the mandatory approval of } \\
\text { this decision by the chief doctor or his/her } \\
\text { deputy on medical work }\end{array}$ \\
\hline 7 & $\begin{array}{l}\text { The procedure } \\
\text { for the appo- } \\
\text { intment of OA } \\
\text { to palliative } \\
\text { outpatients }\end{array}$ & $\begin{array}{l}\text { Outpatients are provided with OA by } \\
\text { HCF or by prescription in pharmacies at } \\
\text { volumes not exceeding the 15-day need; } \\
\text { the doctor who prescribes OA is obligated } \\
\text { to inform the patient or the person caring } \\
\text { for him/her (family member, guardian, or } \\
\text { trustee) about the rules of handling OA, } \\
\text { prohibition of their use not for medical } \\
\text { purposes, and giving the patient or his/her } \\
\text { carer a special information sheet. All of this } \\
\text { should be noted in the medical card of the } \\
\text { patient }\end{array}$ & $\begin{array}{l}\text { Outpatients should be provided with OA by } \\
\text { the HCF only at the place of their residence; } \\
\text { administration of parenteral forms of OA at } \\
\text { home should be carried out only by medical } \\
\text { workers, in particular, the medical staff of the } \\
\text { outpatient clinics, the paramedic and obstetric } \\
\text { stations (rural health posts) at the place of } \\
\text { residence of the patient, with a mandatory } \\
\text { record about that in the medical card of the } \\
\text { patient }\end{array}$ \\
\hline \multirow[t]{2}{*}{8} & $\begin{array}{l}\text { The order of } \\
\text { the destruc- } \\
\text { tion of empty } \\
\text { ampoules and } \\
\text { blisters from } \\
\text { the used OA } \\
\text { in the health } \\
\text { care institu- } \\
\text { tion. }\end{array}$ & $\begin{array}{l}\text { There is no particular procedure for de- } \\
\text { struction of empty ampoules or blisters; } \\
\text { Only the mechanism of the returning to } \\
\text { HCF of unused OA is defined, they should } \\
\text { be subsequently destroyed in accordance } \\
\text { with the procedure established by the law }\end{array}$ & $\begin{array}{l}\text { Every day, except for weekends and holidays, } \\
\text { empty ampoules from used OA should be } \\
\text { returned to the materially responsible persons } \\
\text { to the commission. The destruction of empty } \\
\text { ampoules from the used OA should be carried } \\
\text { out at least once in } 10 \text { calendar days, imme- } \\
\text { diately after that the act on the destruction } \\
\text { must be drawn up and signed by all members } \\
\text { of the commission }\end{array}$ \\
\hline & $\begin{array}{l}\text { The order of } \\
\text { returning of } \\
\text { unused OA }\end{array}$ & This is not indicated & $\begin{array}{l}\text { Empty ampoules and blisters from used OA do } \\
\text { not require additional quantitative accounting } \\
\text { and a particular destruction procedure. } \\
\text { If OA were received at the health care institu- } \\
\text { tions, a family member or carer must return } \\
\text { unused medicines to the doctor (paramedic) } \\
\text { who had prescribed OA or to the responsible } \\
\text { person who delivered them to the patient. } \\
\text { If OA were received by prescription at the } \\
\text { pharmacy, a family member or carer must } \\
\text { ensure disposal of OA }\end{array}$ \\
\hline 9 & $\begin{array}{l}\text { Inventory } \\
\text { check }\end{array}$ & \multicolumn{2}{|c|}{$\begin{array}{l}\text { After the end of the current month, materially responsible persons are obliged to check the } \\
\text { actual quantity of OA with their quantity according to records in the accounting journal. It } \\
\text { should be done on the first day of the next month. } \\
\text { If the actual presence of OA is in deviation with that indicated in the accounting journal, the } \\
\text { health care institution is obligated within } 3 \text { calendar days to carry out an inventory check of } \\
\text { OA, which is listed by this materially responsible person. The procedure of such an inventory } \\
\text { is determined by the legislation }\end{array}$} \\
\hline
\end{tabular}


Table 3. Prescribing of opioid analgesics to palliative patients (Order of MHU No. 360 dated July 19, 2005)

\begin{tabular}{|c|c|c|}
\hline \multirow[t]{2}{*}{ Aspect of the Order } & \multicolumn{2}{|l|}{ Features of prescribing the OA } \\
\hline & in edition until 2013 & in edition since 2013 \\
\hline \multirow[b]{2}{*}{$\begin{array}{l}\text { Who } \\
\text { has the right to write a pre- } \\
\text { scription? }\end{array}$} & \multicolumn{2}{|l|}{ Doctor (physician) } \\
\hline & - & $\begin{array}{l}\text { A medical assistant (paramedic) (for pa- } \\
\text { tients with protracted and chronic diseases } \\
\text { in case of continuation of the treatment } \\
\text { course by the doctor) }\end{array}$ \\
\hline \multirow[t]{2}{*}{$\begin{array}{l}\text { The form } \\
\text { of the prescription }\end{array}$} & \multicolumn{2}{|c|}{$\begin{array}{l}\text { A special blank of pink colour (F-3) } \\
\text { for narcotic and psychotropic medicines is needed }\end{array}$} \\
\hline & & $\begin{array}{l}\text { Since } 2019 \text { there has been an electronic } \\
\text { recipe. It should be filed with an electronic } \\
\text { signature of a healthcare worker in accor- } \\
\text { dance with the legislation on electronic } \\
\text { document circulation and electronic trust } \\
\text { services }\end{array}$ \\
\hline The prescription is valid for & 5 days & 10 days \\
\hline Name of the medicine & Trade name & International non-proprietary name (INN) \\
\hline $\begin{array}{l}\text { The maximum amount of } \mathrm{OA} \\
\text { that can be prescribed and } \\
\text { dispensed to a palliative pa- } \\
\text { tient on one prescription (on } \\
\text { an example of morphine) }\end{array}$ & $\begin{array}{l}\text { Tablets } 5 \mathrm{mg}-20 \text { tablets } \\
\text { Tablets } 10 \mathrm{mg}-10 \text { tablets } \\
\text { Ampoules } 1 \% 1 \mathrm{~mL}-10 \text { ampoules }\end{array}$ & $\begin{array}{l}\text { In one prescription OA in the amount for } \\
\text { a } 15 \text {-day course of treatment may be pre- } \\
\text { scribed (the daily dose of OA is calculated } \\
\text { by the doctor based on the intensity of the } \\
\text { pain and the patient's relief) }\end{array}$ \\
\hline $\begin{array}{l}\text { Peculiarities of the prescrip- } \\
\text { tion requisites }\end{array}$ & $\begin{array}{l}\text { There must be a signature and } \\
\text { personal seal of the doctor, a round } \\
\text { seal of the health care institution, the } \\
\text { signature of the chief doctor or his/ } \\
\text { her deputy on the medical work }\end{array}$ & $\begin{array}{l}\text { Since } 2017 \text { the signature and personal seal } \\
\text { of the doctor, special marks such as «For a } \\
\text { chronic patient», are additionally certified } \\
\text { by a signature and personal seal of the } \\
\text { doctor }\end{array}$ \\
\hline $\begin{array}{l}\text { Place of purchase of OA on a } \\
\text { special prescription }\end{array}$ & $\begin{array}{l}\text { These are pharmacies licensed for acti- } \\
\text { vities on turnover of narcotic drugs } \\
\text { and psychotropic substances. They } \\
\text { are located in one administrative-ter- } \\
\text { ritorial unit (city, district, and region) } \\
\text { with a health care institution and } \\
\text { are attached to it by the order of the } \\
\text { appropriate health care department } \\
\text { of the local state administration }\end{array}$ & $\begin{array}{l}\text { These are pharmacies licensed for activities } \\
\text { on turnover of narcotic drugs and psycho- } \\
\text { tropic substances }\end{array}$ \\
\hline
\end{tabular}

Source: Authors' own development

\section{Pharmacies}

Physical accessibility of patients to OA is important. It is provided by a sufficient number of pharmacies appropriately licensed for this activity. Unfortunately, Ukraine has a poorly developed pharmacy network to provide the population with $\mathrm{OA}$, especially in rural areas [15].

According to data of teh State Service of Ukraine on Medicines and Drugs Control of Ukraine, as of 2019 only $2 \%$ (518 out of 22,980 ) pharmacies have a license for the dispensing of controlled medicines (narcotic medicines, psychotropic substances, and precursors). The majority of such pharmacies (406 pharmacies or $78.8 \%$ ) are located in cities. At the same time, 457 pharmacies (88\%) are of communal property. The largest numbers of such pharmacies are in the western and northern parts of the country (119 and 107, respectively) while in southern and eastern Ukraine there are half as many (47 and 55, respectively). On average, in our country, for one pharmacy that dispense OA, there are 81,578 people. In other countries, this number is $20-46$ times lower: in Latvia - 2560, in Poland - 2300, in Slovakia - 2570, in Bulgaria - 1753, and the Czech Republic - 4015 people. It should be noted that in Latvia, Poland, and Slovakia, all pharmacies without exception must have and dispense a full range of medicines [33].

\section{Current key issues}

Despite the presence in Ukraine of various forms of OA (injections, pills, and syrups), many patients with severe illnesses and chronic pain do not have 
access to adequate pain treatment. This is regularly documented by representatives of human rights organisations. Contemporary key problems in providing patients with $O A$ are:

1. The absence of a national strategy/program for the medical provision of the population with OA. Such a strategy should include clear rules for prescribing, dispensing, administering (including the algorithm for providing the necessary number of procedures, such as parenteral administration, to each patient), recording, storing, and disposing of these medicines. It should also ensure registration of necessary medicines that are not available on the domestic market (for example, oral morphine until 2013) in the short term. Such a strategy should include reimbursement. It is expedient that the state promotes inclusion of OA into the assortment of pharmacies through tax breaks, subsidies, etc.

2. The inconsistency and excessive severity of domestic legislation on the licensing and turnover of narcotic analgesics. Also, there is a problem with a long bureaucratic procedure for the prescription of these drugs.

3. Insufficient provision of population access to pharmacies that dispense OA (more than 81 thousand people served by one such pharmacy). The accessibility of such medicines for the population is especially problematic in rural areas (only one from all the pharmacies (518) is located there).

4. Incompleteness in coverage of the problem of chronic pain pharmacotherapy in terminal patients in programs of higher and secondary medical educational institutions of Ukraine. This leads to low awareness and competence of future doctors and nurses in this area.

That is why measures regarding regulations of $\mathrm{cu}^{-}$ rrent legislation on circulation of $\mathrm{OA}$, and of projects on Higher Education Standards for student training and postgraduate retraining of doctors, paramedics, nurses, and social workers on palliative care are proposed by the "State Narcotic Drug Policy Strategy for the period up to 2020". Approval of medical and technological documents on providing palliative care, treatment of pain syndrome in children and adults, and substitution maintenance therapy is also necessary, as well as national assessment of OA needs, promoting of the expansion of the network of pharmacies that are licensed for activities on OA turnover, improving accessibility of $O A$, and implementation of state regulation of OA prices [34].

\section{Conclusions}

1. Palliative care in Ukraine requires optimisation because of its insufficient provision in hospitals (1500 beds is one third of the number recommended by the WHO), and the lack of a proper care system for incurably ill patients at home. The inadequate level of medical personnel competence, the lack of patient compliance with treatment plans, and the negative effect of the economic component of treatment (lack of public funding and reimbursement) should be emphasised too.

2. The problems of domestic medicine in providing patients with OA are systemic and are due to the lack of a state strategy/program for the development of this sector of medicine and pharmacy. There are also issues with the insufficient number of pharmacy establishments having an appropriate license, too stringent legislative conditions for obtaining a license and conducting such activities by pharmacies, and incomplete assortment of these medicines (no therapeutic transdermal systems).

3. A detailed chronological analysis of the legislative framework on OA turnover in Ukraine over the past 20 years has been carried out. Since 2013 there have been positive changes, in particular regarding the writing of prescriptions on $O A$ for palliative patients: the maximum dose of dispensing $O A$ on one prescription and the local attachment of a pharmacy to HCF have been cancelled.

\section{References}

1. State Statistics Service of Ukraine . http://www.ukrstat. gov.ua (2019 Jun 10).

2. Uncontrolled pain. Ukraine's obligation to ensure evidence-based palliative care. New York, USA: Human Rights Watch 2011 - 127 p. https://www.hrw. org/report/2011/05/12/uncontrolled-pain/ukraines-obligation-ensure-evidence-based-palliative-care (2019 Jun 10).

3. Dudnyk S. Ukrainian realities: light at the end of the tunnel is not visible? https://wwww.vz.kiev.ua/ukrayinski-realiyi-svitla-v-kintsi-tunelyu-ne-vydno/ (2019 Jun 10).

4. Solano JP, Gomes B, Higginson IJ. A comparison of symptom prevalence in far advanced cancer, AIDS, heart disease, chronic obstructive pulmonary disease and renal disease. J Pain Symptom Manage. 2006; 31(1): 58-69, doi: 10.1016/j.jpainsymman.2005.06.007, indexed in Pubmed: 16442483.

5. Cancer Pain Relief: With a Guide to Opioid Availability [Internet]. Geneva: World Health Organization; 1996. http://whqlibdoc.who.int/publications/9241544821. pdf (2019 Jun 10).

6. Access to controlled medications program: improving access to medications under international drug conventions: briefing note. Geneva: World Health Organization; 2009. http://www.who.int/medicines/areas/quality safety/ACMP_BrNoteGenrl_EN_Feb09.pdf (2019 Jun 10).

7. Ensuring balance in national policies on controlled substances: guidance for availability and accessibility of controlled medicines. Geneva: World Health Organization; 2011. https://apps.who.int/iris/handle/10665/44519 (2019 Jun 10).

8. Order of the Ministry of Health of Ukraine No. 311 "On approval and implementation of medical-tech- 
nological documents on standardization of palliative care in chronic pain syndrome" . https://zakon.rada.gov. ua/rada/show/v0311282-12 (25.04.2012).

9. Cancer pain relief [Internet]. Geneva: World Health Organization; 1986. https://apps.who.int/iris/bitstream/handle/10665/43944/9241561009_eng.pdf (2019 Jun 10).

10. Cancer Pain Relief: With a Guide to Opioid Availability [Internet]. Geneva: World Health Organization; 1996. http://whqlibdoc.who.int/publications/9241544821. pdf (2019 Jun 10).

11. Hanks GW, Conno F, Cherny N, et al. Expert Working Group of the Research Network of the European Association for Palliative Care. Morphine and alternative opioids in cancer pain: the EAPC recommendations. Br J Cancer. 2001; 84(5): 587-593, doi: 10.1054/bjoc.2001.1680, indexed in Pubmed: 11237376.

12. Caraceni A, Hanks G, Kaasa S, et al. European Palliative Care Research Collaborative (EPCRC), European Association for Palliative Care (EAPC). Use of opioid analgesics in the treatment of cancer pain: evidence-based recommendations from the EAPC. Lancet Oncol. 2012; 13(2): e58-e68, doi: 10.1016/S1470-2045(12)70040-2, indexed in Pubmed: 22300860.

13. Palliative care for adults: strong opioids for pain relief. Clinical guideline. London: National Institute for Health and Care Excellence; 2012. https://www.nice.org.uk/guidance/cg140? unlid=7810781802015112611725 (2019 Jun 10).

14. Narcotic Drugs Estimated World Requirements for 2019. Statistics for 2017. Vienna: United Nations; 2019. https:// www.incb.org/documents/Narcotic-Drugs/Technical-Publications/2018/INCB-Narcotics Drugs Technical Publication_2018.pdf (2019 Jun 10).

15. Datsiuk NO, Bratsun OP, Volokh DS, et al. Analysis of factors affecting the opioids availability for medical use. Health of Society. 2018; 7(4): 176-180, doi: 10.22141/23062436.7.4.2018.148360.

16. Analytical report. Consumption of opioid analgesics in Ukraine. 2011-2016. Institute of Analytics and Advocacy, International Renaissance Foundation 2018. http://www. irf.ua/knowledgebase/publications/spozhivannya opioidnikh analgetikiv_v_ukraini 20112016 roki/ (2019 Jun 10).

17. Tymoshevska V, Shapoval-Deinega K. Palliative Care Development in Ukraine. J Pain Symptom Manage. 2018; 55(2S): S85-S91, doi: 10.1016/j.jpainsymman.2017.03.031, indexed in Pubmed: 28801000.

18. Shunkina S, Hromovyk B. Palliative care in Ukraine - formation and development. Palliat Med Pract. 2018; 12(2): $1-8$.

19. Shunkina S. Evaluation of the economic availability of chronic pain treatment as a part of HTA in palliative medicine in Ukraine. Value in Health. 2016; 19(3): A247, doi: 10.1016/j.jval.2016.03.1057.

20. Prokip S, Pawlowska I, Hromovyk B, et al. Pharmacist's role in the system of palliative and hospice care in Ukraine and Poland. Journal of Medical Science. 2014; 4: 290-295.

21. Resolution of the Cabinet of Ministers of Ukraine No. 1081 "On Amendments to the National List of Essential Medicines". https://zakon.rada.gov. ua/laws/show/1081 (2017 December 13).

22. Huziy O. Palliative care in Ukraine: what needs to change. Ukrainian medical journal. 2018 Sep. https:// www.umj.com.ua/article/129968/paliativna-dopomoga-v-ukrayini-shho-maye-zminitisya (2019 Jun 10).

23. Law of Ukraine "On Licensing Types of Economic Activities" dated May, 2, 2015, No. 222-VIII. https://zakon.rada.gov. ua/laws/show/222-19 (2019 Jun 10).
24. Buhayevska N, Buhayevsky K. Peculiarities of the training of nurses for palliative and hospice care in Ukraine and Poland. Current scientific researches in the modern world. 2016; 12-2. ; 20: 40-45.

25. Order of the Ministry of Health of Ukraine No. 77 dated 01.02.2013 "On State Registration (Re-registration) of Medicinal Products and Changes to Registration Materials. https://zakon.rada.gov.ua/rada/show/v007728213 (2019 Jun 10).

26. Law of Ukraine "About narcotic drugs, psychotropic substances and precursors" No. 61/95-VR dated February, 15, 1995. https://zakon.rada.gov. ua/laws/show/60/95 (2019 Jun 10).

27. Resolution of the Cabinet of Ministers of Ukraine No. 770 dated 6 of May, 2000 "About approval of the list of narcotic drugs, psychotropic substances and precursors". https://zakon.rada.gov.ua/laws/show/7702000 (2019 Jun 10)

28. Order of the Ministry of Health of Ukraine No. 360 dated July, 19, 2005 "About approval of the rules for writing of prescriptions and requirements-orders for medicines and medical products, the procedure for the dispensing of medicines and medical products from pharmacies and their structural subdivisions, instructions on the procedure for storage, accounting and destruction of prescriptions and requirements-orders". https://zakon3.rada.gov. ua/laws/show/z0782-05 (2019 Jun 10).

29. Resolution of the Cabinet of Ministers of Ukraine No. 589 dated June, 3, 2009 "About approval of the procedure for the activities of the circulation of narcotic drugs, psychotropic substances and precursors, and the control over their turnover". https://zakon.rada.gov. ua/laws/show/589 (2019 Jun 10).

30. Resolution of the Cabinet of Ministers of Ukraine No. 333 dated May, 13, 2013 "About approval of the procedure for the purchase, transportation, storage, dispensing, usage, and destruction of narcotic drugs, psychotropic substances and precursors in health care institutions". https://zakon3.rada.gov. ua/laws/show/333 (2019 Jun 10).

31. Order of the Ministry of Health of Ukraine No. 494 dated August, 7, 2015 "About some issues of purchase, transportation, storage, dispensing, usage, and destruction of narcotic drugs, psychotropic substances and precursors in health care facilities". https://zakon.rada.gov. ua/laws/show/z1028-15 (2019 Jun 10).

32. Order of Ministry of Health of Ukraine No. 11 dated January, 21, 2010 "About approval of the procedure for the turnover of narcotic drugs, psychotropic substances and precursors in health care facilities of Ukraine". https://zakon.rada.gov.ua/laws/show/z034710 (2019 Jun 10).

33. Regulatory and legal adjustment of physical accessibility of outpatients to opioid analgesics. http://farmpalata.com.ua/novyny/normatyvno-pravove-vregulyuvannya-zabezpechennya-fizychnoyi-dostupnosti-patsiyentiv-yaki-perebuvayut-na-ambulatornomu-likuvanni-do-opioyidnyh-znebolyuvalnyh-likiv/?fbclid=IwAR3ntgCOoWjqNK4d-whFqpBUUiGRWAMtyieWdx92c64aaYpOBZNE3n8XmrY (2019 Jun 10).

34. Ordinance of the Cabinet of Ministers of Ukraine dated February, 6, 2019 № 56-r «On Approval of the Action Plan for 2019-2020 on the Implementation of the State Narcotic Drug Policy Strategy for the period up to 2020». https://zakon.rada.gov.ua/laws/show/562019-\%D1\%80 (2019 Jun 10). 